M. Daireaux generalmente falsean el sentido de esos capítulos o párrafos y tienen un alcance opuesto al que se perseguía. En efecto, contradicen la afirmación del crítico-historiador por mil razones.

Este artículo también le parecerá a M. Daireaux muy insuficiente, aunque tal vez no injurioso. Pero ¿qué hacerle? Analizar con pruebas las afirmaciones erradas, las omisiones y tergiversaciones innumerables del autor no es obra de un artículo ni de diez. Es obra de un libro, que naturalmente no podemos escribir porque no hay manera de que salga de inédito.

El señor Daireaux parece creer que en América no se le agradece la intención que ha tenido y amenaza al final de su artículo con despreocuparse en lo futuro de las cosas americanas. Está equivocado. Se le agradece mucho lo que ha hecho; pero ¿no es legítimo también anheTar que lo realizado fuese menos malo? Haga el señor Daireaux una segunda edición de su libro $\mathrm{y}$ tome en cuenta en ella las observaciones que se le han hecho. Entonces veremos si era posible esperar de él algo más que este insuficiente Panorama y que su ardiente pero débil defensa que hemos comentado a vuelo de pluma.- $R$ A U L SIL V A CASTRO.

\title{
EN TORNO A LA POLITICA EUROPEA
}

Berlin, Septiembre de 1930.

ESDE la iniciación del período de profundas agitaciones político-sociales que dejó la guerra, Europa vive hoy sus tiempos de mayor incertidumbre. El panorama político europeo aparece cada vez más confuso e inquietante. Es una exclamación bastante generalizada entre las gentes que confían excesivamente en la acción de los guías geniales, que a Europa le faltan en estos tiempos grandes hombres. Los comunistas creen en la grandeza de Stalin, los fascistas en la genialidad de Mussolini e Hitler, los liberales en la sabiduría política de Briand. Los socialistas no hallan ni en Mac Donald ni en los líderes alemanes un hombre digno de sus esperanzas. Los observadores y los estudiosos más o menos imparciales dudan de la influencia europea de todas las figuras eminentes de esta 
época que frente a los graves problemas internos de cada paísRusia, Italia, Inglaterra, Francia o Alemania- no tienen tiempo ni fuerza para irradiar sus prestancias de conductores continentales.

La guerra ha dejado profundos e innumerables problemas. En los primeros años de la paz forzosa, se creyó en la muerte definitiva y pronta del sistema capitalista europeo por la revolución que Rusia anunciaba al viejo mundo. Parecía evidente que el proletariado de la Europa industrial acudiría pronto al llamado comunista. La influencia moral de Rusia y de sus grandes guías apareció irresistible. Europa cuenta con el proletariado más numeroso, más antiguo, más consciente, más sufrido y más listo para las luchas de clase. Si una potencia de la importancia de Rusia enarbolaba la bandera de la revolución, todos los pronósticos se inclinaban a esperar que las clases obreras, desangradas por la guerra, mordidas por la miseria, comprenderían que-con las palabras del célebre manifiesto de Marx-tomar el camino de la rebeldía, sólo implicaba perder cadenas para ganar un mundo.

Después de un decenio de intensos fracasos, la revolución social no se ha producido todavía. El proletariado de los grandes países industriales no ha lanzado aún su grito de insurrección. El partido comunista internacional, relativamente numeroso en Alemania y en Francia, casi insignificante en Inglaterra-el país de las más antigua, organizada y fuerte clase obrera de Europa-, no demuestra haber alcanzado la fuerza suficiente para tomar el poder. En Italia, el fascismo ha dominado a las masas con su arrogancia nacionalista. En el resto de Europa, frente a cada intento de rebeldía, han surgido poderosas las falanges contrarias.

Los observadores de este interesante fenomeno han intentado interpretarlo desde distintos puntos de vista. ¿Falta de grandes guías? ¿Influencia desviadora de los jefes reformistas? ¿Impreparación de la clase obrera para asumir el poder? ¿Consistencia del sistema capitalista? ¿Influencias de los Estados Unidos? A cada pregunta se ha respondido diversamente. Los individualistas han señalado como motivo determinante de la falta de ímpetu revolucionario en las clases proletarias europeas la ausencia de verdaderos directores o la abundancia de malos. En esta afirmación-y desde otro punto de vista-coinciden muchos voceros de la izquierda extrema. Los socialistas ortodoxos replican que la responsabilidad histórica de la actitud no revolucionaria de la mayoría de la clase obrera de Europa, no puede gravitar sobre los conductores. 
Sería-dicen-renegar de la concepción social del desenvolvimiento humano: a la historia no la hacen virar los individuos cuya influencia no es causa sino efecto de la realidad social. Para los socialistas, la hora de la revolución no ha llegado porque si así fuera ya estaría hecha a pesar de todos los malos guías. Los partidarios y devotos del capitalismo proclaman la perdurabilidad del sistema. Los nacionalistas insisten en la omnipotencia de los intereses y sentimientos circunscritos por las fronteras de cada patria. Los más optimistas convienen en que fué error del comunismo ruso someter la marcha de la revolución a un itinerario. Según ellos, la revolución vendrá, pero es audaz e inocente señalarle plazo fijo.

E.n esta vasta controversia es difícil distinguir la observación desinteresada de la propaganda partidista. Empero, la realidad de la Europa actual continúa inquietando la mente de los intérpretes. La revolución proletaria europea-que se anunció insistentemente como consecuencia inmediata de la guerra--no se ha producido aún, y Rusia, país predominantemente agrario, ha tenido que enfocar directamente el problema de su industrialización para librarse así de la dependencia de los países capitalistas. Para su política de industrialización Rusia necesita de las relaciones con los pueblos industriales, y como la Europa industrial necesita de los productos agrarios y de las materias primas de Rusia, las conexiones diplomáticas y los convenios comerciales han sido imperativos. Con ellos se han ajustado condiciones de no interferencia política-expresamente ratificadas en el último tratado con Inglaterra y en el recientísimo acuerdo con Alemania-, que limitan sin duda la acción política internacional de Moscú subordinándola a una imperiosa e inmediata necesidad interna. El esfuerzo de Rusia hacia la industrialización impone la concentración de todas sus energías para realizar un proyecto gigante limitado al plazo de un lustro. Para adquirir máquinas-capital fijo-, Rusia debe exportar productos agrícolas y materias primas-capital circulante-. Ese esfuerzo estupendo, sin precedentes en la historia económica, impone el aplazamiento de otras actividades y exige paz. El problema presente de Rusia es industrializarse para cumplir apresuradamente la etapa capitalista, bajo la dictadura del proletariado, y consumar después el ideal comunista. El problema presente de la Europa capitalista es aprovechar esta tregua y consolidar su viejo sistema.

En las zonas de Europa, la del capitalismo y la del comunismo, se produce, pues, con distintos objetivos, un fenómeno de afirmación económica nacional. Rusia vincula a su unidad 
de sistema su unidad férrea de dirección. La Europa occidental sigue su marcha, dentro de un sistema establecido sin hallar hasta ahora una línea política común. Rusia confía en el fracaso del capitalismo de occcidente y la Europa burguesa espera que Rusia no salve los riesgos de su tremendo esfuerzo por acelerar su evolución.

Para conseguir la unidad de dirección política de la Europa occidental se intentan todas las formas de organización política. Los conservadores nacionalistas sostienen la necesidad de afirmar las viejas instituciones, ya por los transitados caminos de la política del zapa, del armamentismo y del refuerzo del capitalismo, ya por los medios violentos de agresividad reaccionaria y de intolerancia implacable. Los liberales y democráticos propugnan, con el auxilio de los socialistas, la federación de Europa, la limitación de armamentos, la cooperación internacional dentro del presente sistema económico. Los comunistas, como desde hace doce años, continúan urgiendo al proletariado a la revolución. La lucha de estas fuerzas no define victorias. Los nacionalistas-particularmente los de filiación fascista-no cejan en su grita guerrera. En Italia amenazan a Francia. En Alemania piden desquite contra los vencedores. Frente a la propaganda bélica surge la proyectada unión' de Europa. Pero los nacionalistas acusan a Francia, defensora de la iniciativa, de buscar su hegemonía y seguridad. Inglaterra que es reino y es imperio no puede comprometerse a una desintegración de sus dominios y colonias, implicada en el supuesto de su ingreso a la federación proyectada. De otro lado, el plan de Pan-Europa excluye a Rusia, y en el caso más actual, supone un frente único contra los Fstados Unidos, autoridad suprema de las finanzas de Europa, mientras se paguen las fantásticas deudas de la guerra.

El problema no puede ser más complicado. Lo lejano de su solución explica la incertidumbre inquietante de Furopa. Ninguna fuerza parece suficientemente poderosa para imponerse. Ningún hombre suficientemente grande que concite la autoridad necesaria para guiarla. Europa vive en trance de crisis. Se creyó que la guerra sería como la cura trágica de sus males. Pero todos los pronósticos, todas las profecías han fracasado hasta hoy. Renace el presentimiento siniestro: ¿guerra de clases?, ¿guerra de naciones? Algo anuncia que la sangre vertida no ha sido suficiente. $Y$ todo espera Europa, menos la paz.- H A Y A D L A T O R R E.

Exclusivo para Atenea en Chile. 